Acta vet. scand. 1971, 12, 592-600.

From the Department of Microbiology and Immunology,

Veterinary College of Norway, Oslo.

\title{
THE EFFECT OF MICROBIAL AND \\ ANIMAL PRO'TEINASES ON PEPTIDE- AND PROTEIN-LIGNOSULPHONIC ACID COMPLEXES IN AGAR GEL
}

\author{
By \\ Bjфrn Næss
}

In the previous studies on the precipitating ability of lignosulphonic acids on peptides and proteins, no precipitate was obtained when lignosulphonic acids were added to dipeptide solutions under various conditions (Næss $1971 \mathrm{a}$ ). The theory was proposed that the peptides have to exceed a minimum molecular size in order to form precipitates with lignosulphonic acids.

Agar gel was found to be convenient as a support medium for the experiments with this system.

The aim of the present work was to find out whether various animal and microbial proteinases are able to decompose the peptides and proteins of the precipitates with lignosulphonic acids, and thus exhibit a lytic or digestive effect on the precipitates in agar gel.

\section{MATERIALS AND METHODS}

Lignosulphonic acids. The lignosulphonic acids were prepared by precipitation of sulphite spent liquor with $\mathrm{CaO}$, dissolution of the precipitate in $0.01 \mathrm{M}-\mathrm{HCl}$, and dialysis of the solution against tap water after neutralizing with $0.1 \mathrm{M}-\mathrm{NaOH}$, as described by Næss (1971 a). Dialysed sulphite spent liquor was sometimes used as the source of lignosulphonic acids. The sulphite spent liquor was kindly supplied by A/S Tofte Cellulosefabrik, Hurum, Norway. 
Peptide- and protein-lignosulphonic acid agar plates. Lignosulphonic acids, thimerosal and one of the following peptides or proteins were added to melted Bacto-agar (Difco* 0140-01) : Neopeptone (Difco 0119-01), proteosepeptone (Difco 0120-01) or bovine serum albumine (Sigma ${ }^{\star}$ ). The different ingredients were added to the melted agar and mixed, immediately before pouring the medium into Petri dishes or rectangular glass plates prepared as described in a previous work (Næss $1971 \mathrm{~b}$ ). The pH in the agar was adjusted by adding $1 \mathrm{M}-\mathrm{HCl}$. The thickness of the agar layer was adjusted to $2 \mathrm{~mm}$. The final concentrations of the substances were as follows: Agar 0.7 \%; lignosulphonic acids $5 \%(\mathrm{v} / \mathrm{v})$ of a solution containing 250 diffusion units of peptideprecipitating lignosulphonic acids per $50 \mu \mathrm{l}$ liquor (Næss $1971 \mathrm{~b}$ ); thimerosal $0.01 \%$; peptides or proteins $0.1-10.0 \%$. A $5 \%$ concentration of lignosulphonic acids was found suitable in order to obtain significant opacity in the agar plates at the peptide and protein concentrations used. For the application of the enzymes to be tested, circular wells, $7 \mathrm{~mm}$ in diameter, were cut in the agar layer with the aid of a cork borer.

Enzymes. The bacterial proteinases were produced according to a procedure described by Sandvik (1962), and endocellular yeast proteinases were prepared as described by Fossum (1970 b). The following strains were used: Bacillus cereus ( $\mathrm{NVH}^{\star \star \star}$ 322), Pseudomonas aeruginosa (NVH 982), Serratia marcescens $(\mathrm{NCIB} \dagger$ 1371), Candida utilis (ATCC $\dagger \dagger$ 9226) and Saccharomyces cerevisiae var. ellipsoideus (ATCC 7753). Bovine trypsin (type III, $2 \times$ crystallized, lot $97 \mathrm{~B}-8000$ ) and Aspergillus oryzae protease (type II, crude, lot 1320) were obtained from Sigma, trypsin ex hog pancreas (crystallized, batch no. 36467) and pepsin ex hog stomach mucosa ( $3 \times$ crystallized, batch no. 44613) from Koch-Light $\uparrow \dagger \dagger$. The enzyme solutions were applied into the agar wells in $50 \mu \mathrm{l}$ volumes. Dry weight is only used for the commercially obtained proteinases.

* Difco Laboratories Inc., Detroit, USA.

* * Sigma Chemical Company, St. Louis, Missouri, USA.

*** The Culture Collection at the Department of Microbiology and Immunology, Veterinary College of Norway, Oslo, Norway.

$\dagger$ National Collection of Industrial Bacteria, Torry Research Station, Aberdeen, Scotland.

$\dagger \dagger$ American Type Culture Collection, Rockville, Maryland, USA. $\dagger \dagger \dagger$ Koch-Light Laboratories, Colnbrook, Bucks., England. 
Serum. Antibovine trypsin was produced in rabbit according to a procedure described by Sandvik. In addition to the specific antienzyme, the serum contained normal inhibitors against the enzymes as described by Fossum (1971). These inhibitors are situated in the $\alpha$ - and $\beta$-globulin fractions.

Demonstration of antitrypsin effect. The antiserum was subjected to paper electrophoresis before being brought into contact with the enzyme. After electrophoresis, the wet paper strips were transferred to the surface of a neopeptone-lignosulphonic acid agar plate and incubated for $3 \mathrm{hrs}$. at $37^{\circ} \mathrm{C}$. The strips were then removed from the agar layer and replaced by narrow strips of filter paper that had been immersed in a bovine trypsin solution $(0.1 \mathrm{mg} / \mathrm{ml})$. After further incubation at $37^{\circ} \mathrm{C}$ for $15 \mathrm{hrs}$., the enzyme-containing strips were removed. This procedure corresponds to the casein precipitation inhibition test (Sandvik; Dahle 1969) with the exception that the peptide-lignosulphonic acid complex is substituted for sodium caseinate.

Chemicals. All chemicals used were of analytical grade.

\section{RESULTS}

Peptide- and protein-lignosulphonic acid agar plates, with the $\mathrm{pH}$ varying from 3.6 to 6.8 , and with the concentration of peptides, or proteins, varying from 0.1 to $10.0 \%$, were used. Under the conditions studied, the opacity of the agar plates increased with increasing concentrations of peptides, or proteins, when the lignosulphonic acid concentration was held constant, as was also demonstrated for neopeptone-lignosulphonic acid agar in a previous work (Næss 1971 a). When solutions of proteolytic enzymes were applied into the agar wells, and the plates incubated at $37^{\circ} \mathrm{C}$, distinct circular zones of total lysis appeared after $20-30 \mathrm{~min}$. around some of the enzyme containing wells on pletes containing $0.1-1.5 \%$ peptides or proteins. If the plates contained higher concentrations of the peptides or proteins, the lysis zones appeared only after longer incubation times. On plates containing $7-10 \%$ peptides, or proteins, zones of lysis did not appear at all within 24 hrs'. incubation for any of the enzymes tested. Fig. 1 shows $1.5 \%$ neopeptone-lignosulphonic acid agar plates after incubation with different enzymes applied into the wells. When saline, or distilled water, was applied instead of enzyme solutions, lysis or any other type of zone formation failed to occur. Under 


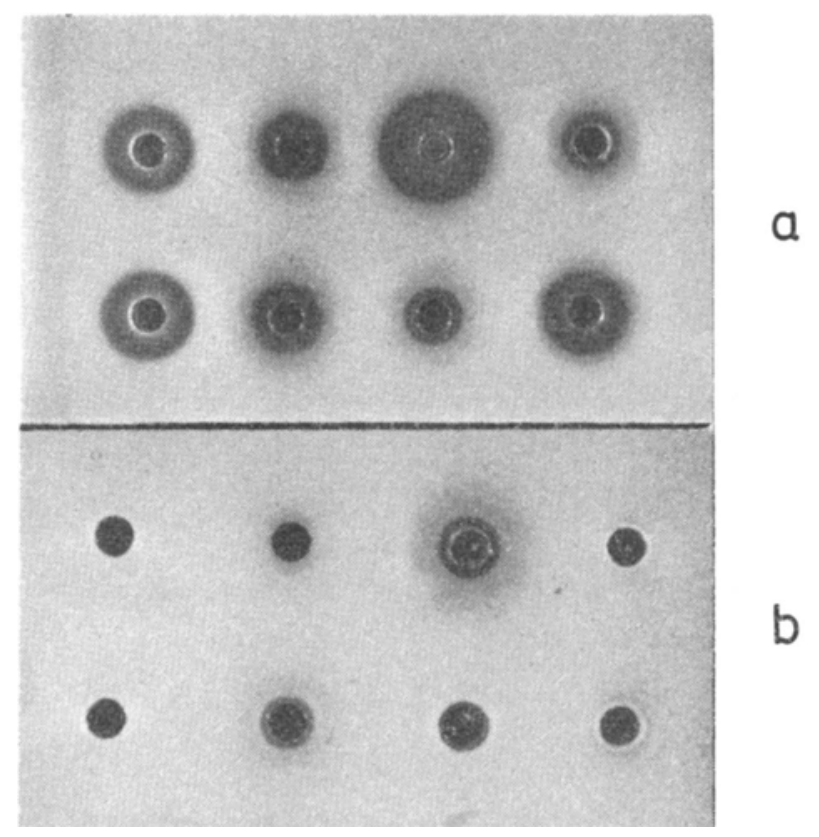

Figure 1. Neopeptone (1.5\%)-lignosulphonic acid agar plates with $50 \mu 1$ of various proteolytic enzyme solutions applied in circular wells. The enzyme solutions are from the upper left to the lower right: Swine trypsin $(0.1 \mathrm{mg} / \mathrm{ml})$, Pseudomonas aeruginosa proteinase, Aspergillus oryzae proteinases $(15 \mathrm{mg} / \mathrm{ml})$, Saccharomyces cerevisiae proteinase, bovine trypsin $(0.1 \mathrm{mg} / \mathrm{ml})$, Bacillus cereus proteinase, Serratia marcescens proteinase and Candida utilis proteinase. a: $\mathrm{pH}$ 6.8. b: $\mathrm{pH} 3.6$. Incubation time $15 \mathrm{hrs}$. at $37^{\circ} \mathrm{C}$.

the conditions studied, the diameter of the zones decreased when reducing the $\mathrm{pH}$ in the plates. At $\mathrm{pH} 3.6$ only Aspergillus oryzae proteinases, Bacillus cereus proteinase and Serratia marcescens proteinase resulted in visible lysis zones (Fig. $1 \mathrm{~b}$ ). A $1.5 \%$ neopeptone agar plate with $\mathrm{pH} 2.0$ was prepared for testing the effect of pepsin, but no lysis zones were obtained within $24 \mathrm{hrs}$. of incubation with solutions containing $0.5,1.0$ and $2.0 \mathrm{mg}$ pepsin per ml.

For preparing plates with low $\mathrm{pH}$, neopeptone proved to be the most suitable of the peptides and proteins used, because of its $\mathrm{pH}$ stability. Under the conditions studied, the diameter of the lysis zones increased with increasing incubation time, and with decreasing concentration of peptides or proteins as demonstrated for Pseudomonas aeruginosa proteinase in neopeptone- 


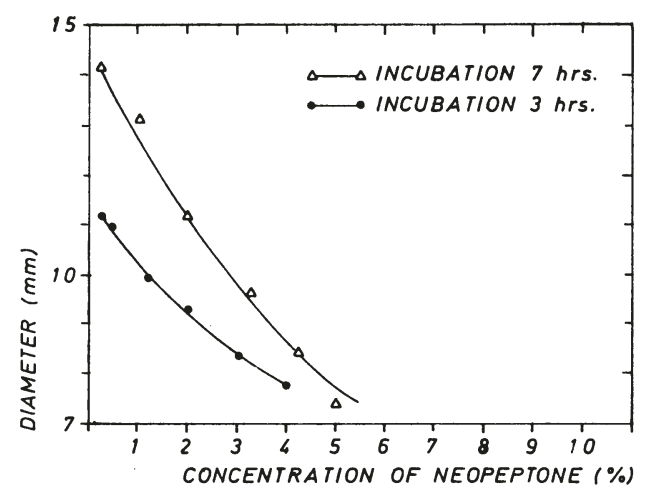

F i g u r 2. Diameter of lysis zones caused by Pseudomonas aeruginosa proteinase in neopeptone-lignosulphonic acid agar plates as a function of the neopeptone concentration. $\mathrm{pH} 6.2$. Incubation at $37^{\circ} \mathrm{C}$.

lignosulphonic acid agar plates in Fig. 2. In Fig. 3 the relation is shown between enzyme concentration and diameter of lysis zones caused by bovine trypsin and Aspergillus oryzae proteinases at $\mathrm{pH} 6.2$ and 4.5. The highest dilutions of trypsin and Aspergillus oryzae proteinases resulting in lysis zones after 18

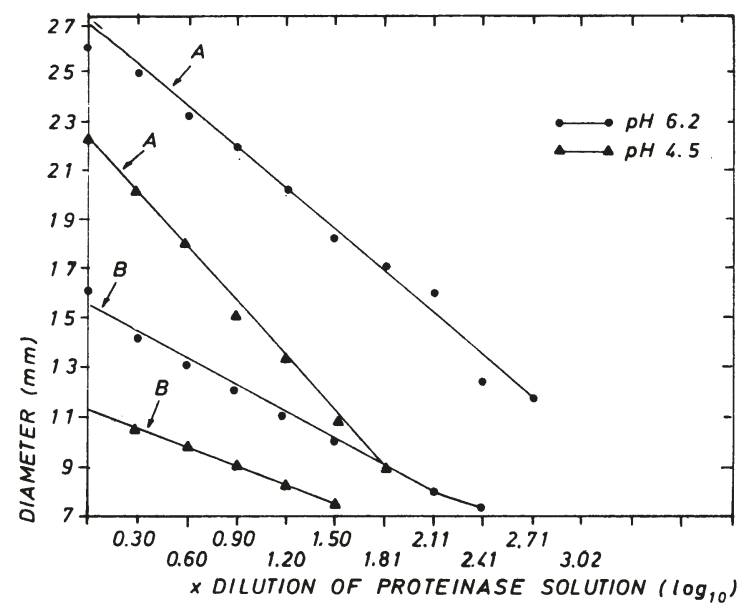

F i g u re 3. Relation between enzyme concentration and zones of lysis caused by Aspergillus oryzae proteinase (A) and bovine trypsin (B) at $\mathrm{pH} 6.2$ and 4.5 in neopeptone $(1.5 \%)$-lignosulphonic acid agar plates. Application $50 \mu l$ and initial concentration of bovine trypsin $1 \mathrm{mg} / \mathrm{ml}$, and for Aspergillus oryzae proteinases $30 \mathrm{mg} / \mathrm{ml}$. Incubation time $18 \mathrm{hrs}$. at $37^{\circ} \mathrm{C}$. 
hrs'. incubation at pH 6.2 were of the order of $\frac{1}{250}$ and $\frac{1}{500}$ respectively, as compared with $\frac{1}{10,000}$ and $\frac{1}{10,000}$ (Fossum 1970 a) for precipitation zones with the casein precipitation test, when the initial concentration of trypsin was $1 \mathrm{mg} / \mathrm{ml}$, and of Aspergillus oryzae proteinases $30 \mathrm{mg} / \mathrm{ml}$. The highest dilutions of the enzymes which resulted in lysis zones at $\mathrm{pH} 4.5$ were of the order $\frac{1}{30}$ and $\frac{1}{250}$ respectively. The electrophoretical pattern for antiserum against bovine trypsin, transferred to neopeptone-lignosulphonic acid agar and developed with two different enzyme solutions, is shown in Fig. 4. It can be seen from the figure that the lytic activity of bovine trypsin is inhibited by specific antitrypsin and by the naturally occurring serum inhibitors, while the activity of Pseudomonas aeruginosa proteinase is only inhibited by the naturally occurring serum inhibitors.

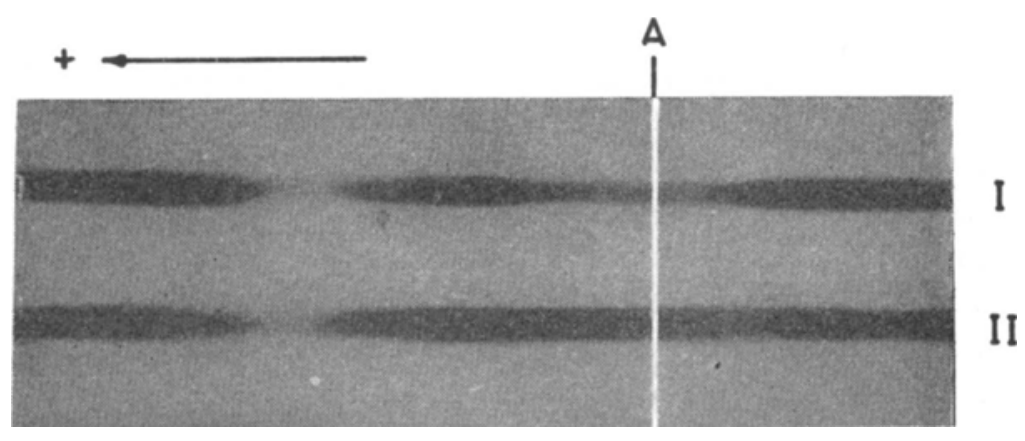

Fig u r e 4. Electrophoretical pattern for antiserum against bovine trypsin, transferred to a neopeptone $(1.5 \%)$-lignosulphonic acid agar plate. Developing was performed with 2 different enzyme solutions. I: Homologous reaction when trypsin antiserum is developed with trypsin. II: Trypsin antiserum developed with Pseudomonas aeruginosa proteinase. The specific antibodies are localized in the area of the line of application (A). The normal serum inhibitors are seen to the left of this line. The electrophoresis ${ }^{\star}$ was carried out in $0.05 \mathrm{M}$ phosphate buffer, $\mathrm{pH} 6.2$ for $18 \mathrm{hrs}$. at $120 \mathrm{v}$.

${ }^{\star}$ LKB equipment for paper electrophoresis, LKB Instruments Itd., Stockholm, Sweden. 


\section{DISCUSSION}

As shown in Fig. 1, solutions of proteolytic enzymes applicated into wells in peptide-lignosulphonic acid agar plates cause distinct lysis zones around the wells, in the otherwise opaque medium, while saline or distilled water has no lytic effect. The inhibitory effect of specific antitrypsin, and naturally occurring serum enzyme inhibitors, on the lytic action of trypsin (Fig. 4), seems to prove that the lytic effect caused by the enzyme solutions is due to proteolytic activity. Fig. 4 also shows that peptides or proteins combined with lignosulphonic acids can serve as substrate for certain proteolytic enzymes. A possible explanation of the reaction mechanism is that the precipitated complex becomes unstable when its peptide or protein factors are digested into smaller units. This is in accordance with the precipitation theory discussed previously (Næss $1971 \mathrm{a}$ ). Whether the proteinases act on the probable amino-sulphonic acid bond, and whether small peptides combine with lignosulphonic acids without forming precipitating complexes, still have to be elucidated. The lysis zones described here are essentially different from the central lysis zones in peptide-lignosulphonic acid precipitation zones, which are probably caused by an excess of lignosulphonic acids, and from the precipitation zones caused by proteolytic enzymes in caseinate agar plates (Næss 1971 a).

In the present work no visible proteinase-lignosulphonic acid complex has been observed in the lysis zones on the plates.

Vocac \& Alphin (1968) have studied the effect of lignosulphonic acids on experimental gastric ulceration in rats and found that certain lignosulphonic acids are competitive inhibitors of pepsin proteolysis and that the inhibitory effect is quite specific. Thus, it was not unexpected that no lytic effect was found with pepsin solutions in this study. Biological activity was, however, observed for all the other proteinases tested when acting in the peptide-lignosulphonic acid system.

It is also clear that the specific antiproteinase, and the naturally occurring serum enzyme inhibitors, do not lose their biological activity when acting in peptide-lignosulphonic acid agar under the conditions used (Fig. 4).

Extra- and intra-cellular microbial proteinases are responsible for an important part of the biochemical activity in many ecosystems, and it is of great interest to study the activity of proteinases in complex ecosystems, such as fiord basins and rivers, into which 
lignosulphonic acids are released. Various microorganisms and other organic materials usually comprise a considerable part of these ecosystems (Schmidt 1967), and the present studies may indicate an important type of reaction which may occur in such systems.

The characteristic activity of proteolytic enzymes in peptidelignosulphonic acid agar plates indicates that this agar system can be used as a tool for studying certain proteolytic enzymes under various conditions, particularly at low $\mathrm{pH}$ values. This observation is of interest because the casein precipitation test and the casein precipitation inhibition test described by Sandvik (1962) for studying proteolytic enzymes, cannot be utilized for systems with $\mathrm{pH}$ values lower than 5.5, due to the $\mathrm{pH}$ lability of the sodium caseinate micelle. Significant activity of acid resistant proteolytic enzymes was demonstrated at $\mathrm{pH} 3.6$ using the peptide-lignosulphonic acid complex as substrate. At $\mathrm{pH} 6.2$ the casein precipitation test was found to be considerably more sensitive than the described procedure when bovine trypsin and Aspergillus oryzae proteinases were tested. The sensitivity of the described procedure seems to correspond more with the appearance of inner lysis zones in the caseinate precipitation zones of the casein precipitation test.

\section{REFERENCES}

Dahle, H. K.: Enzymoserological separation of bacterial proteinases. Acta path. microbiol. scand. 1969, 77, 143-148.

Fossum, K.: Proteolytic enzymes and biological inhibitors. I. Comparison between the Kunitz method and the Agar Gel Casein Precipitating reaction for determination of the activity of some commercial proteolytic enzymes and inhibitors. Acta path. microbiol. scand. 1970 a, $78 B, 350-362$.

Fossum, K.: Proteolytic enzymes and biological inhibitors. IV. Bacterial proteinase inhibitors and their effect upon enzymes of various origin. Acta path. microbiol. scand. $1970 \mathrm{~b}, 78 \mathrm{~B}, 755$ 759.

Fossum, K.: Proteolytic enzymes and biological inhibitors. V. Serological relationship between bovine and swine trypsins and bovine $\alpha$-chymotrypsin. Acta vet. scand. 1971, 12, 417-428.

Næss, $B$.: The precipitation of peptides and proteins by lignosulphonic acids. Acta vet. scand. 1971 a, 12, 572-582.

Ness, B.: Peptide-lignosulphonic acid precipitation zones in agar gel. A direct micro quantitative procedure for the determination of peptide-precipitating lignosulphonic acids in aqueous solution. Acta vet. scand. $1971 \mathrm{~b}, 12,583-591$. 
Sandvik, O.: Studies on casein precipitating enzymes of aerobic and facultatively anaerobic bacteria. Thesis. Veterinary College of Norway, Oslo 1962.

Schmidt, H.: Sulfitablauge und Wasserwirtschaft. (Sulphite spent liquor and water science). In Verwertungsgebiete für Sulfitablauge. (Applications of sulphite spent liquor). Ed. F. Melms \& K. Schwenzon. VEB Deutscher Verlag für Grundstoffindustrie, Leipzig 1967, 465-490.

Vocac, J. A. \& R. S. Alphin: Effects and mechanism of action of a lignosulphonate on experimental gastric ulceration in rats. Europ. J. Pharmacol. 1968, 4, 99-102.

\section{SUMMARY}

It is shown that various microbial and animal proteinases, with the exception of pepsin, have a lytic effect on peptide- and proteinlignosulphonic acid complexes in agar gel, and that this effect is characteristically inhibited by specific antiproteinases and naturally occurring serum inhibitors. The activity of the enzymes is studied at various concentrations of peptides and proteins, and at various $\mathrm{pH}$ values in the agar. The lysis phenomenon is seen in relation to the precipitation theory of peptide- and protein-lignosulphonic acid complexes, and to biochemical reactions taking place in certain natural ecosystems. Activity caused by different microbial proteinases is demonstrated in agar plates at $\mathrm{pH}$ 3.6. The possibility of using the method for studies on proteolytic enzymes at low $\mathrm{pH}$ values is suggested.

\section{SAMMENDRAG}

Virkningen av mikrobielle og animale proteinaser på peptid-og protein-ligninsulfonsyre-komplekser $i$ agar medier.

Det er vist at forskjellige mikrobielle og animale proteinaser med pepsin som unntak har lytisk virkning på peptid- og protein-ligninsulfonsyre-komplekser i agar gel og at denne effekt hemmes på karakteristisk vis av spesifikke antiproteinaser og naturlig forekommende inhibitorer i serum. Enzymenes virkning er studert for forskjellige konsentrasjoner av peptider og proteiner og med forskjellige $\mathrm{pH}$ verdier $\mathrm{i}$ agargelen. Lysisfenomenet er diskutert $\mathrm{i}$ relasjon til presipitasjonsteorien for peptid- og protein-ligninsulfonsyre-komplekser og i relasjon til biokjemiske reaksjoner som skjer i visse $\phi$ kosystemer. Det er demonstrert aktivitet av forskjellige proteinaser $\mathbf{i}$ agar plater ved pH 3.6. En har antydet muligheten for å bruke den beskrevne metode til studier av proteolytiske enzymer ved låge $\mathrm{pH}$-verdier.

(Received November 28, 1970). 